\title{
The Yuktidīpika on the Origin of the Vedas
}

\author{
Ołena Lucyszyna
}

(C) The Author(s) 2020. This article is published with open access at Springerlink.com

\begin{abstract}
In this article, I reconstruct the view of the Yuktidipika $\bar{a}$, the most detailed and profound commentary of classical Sāmkhya, on the origin of the Vedas. A close reading of the text reveals that its unknown author wavered between at least two different views on this issue. The first view is that the authorless but noneternal Vedas evolve from prakrti (primordial matter) at the beginning of a new cycle of existence of the world (kalpa) and merge into prakrti during a cosmic dissolution (pralaya). The Yuktidīpikā is the first text in classical Sāmkhya to state directly that the Vedas have no author. The second and opposite view is that Kapila is the author of the highest teaching of the Vedas. This view is expressed only indirectly. Besides reconstructing the above-mentioned views, I attempt to answer the question of whether by quoting Nirukta 1.20 the Yuktidīpikā communicates something about the origin of the Vedas. Illustrating Sāmkhya thought by quoting this passage of the Nirukta, as well as proclaiming the idea that the Vedas are authorless, which became the "official" standpoint of the Sāmkhya darśana, can be interpreted as elements of the Yuktidīpikā's pioneering project to show that Sāmkhya is not in conflict with the Vedas.
\end{abstract}

Keywords Yuktidīpikā · classical Sāmkhya · the Vedas · authorless (apauruṣeya) • Kapila $\cdot$ Nirukta

Ołena Łucyszyna

o_lutsyshyna@yahoo.co.uk

University of Humanities and Economics in Lodz, ul. Sterlinga 26, 90-212 Lodz, Poland 


\section{Introduction}

In this article, I reconstruct and critically explain the view of the Yuktidipika (ca. 600-700 CE), ${ }^{1}$ the most detailed, profound, and polemical commentary of classical Sāmkhya, on the origin of the Vedas. The problem of the origin of the Vedas, vividly discussed in Indian philosophy, encompasses the following questions: Are the Vedas eternal? Do they have an author? How do they come into existence? The main contributors to this discussion are Mīmāmsāa and its rival schools Nyāya and Vaiśeșika. For Mīmāṃsā, the Vedas are authorless and eternal; they were never created and will never be destroyed. According to Nyāya and Vaiśeșika, the Vedas are created (in fact, recreated) by the primeval $r s i \mathrm{~s}^{2}$ or Íśvara ${ }^{3}$ at the beginning of a new cycle of existence of the world. What is the Sāmkhya view presented in the Yuktidipika, one of the most important commentaries of this darśana?

The issue of the origin of the Vedas according to the Yuktidipika was touched upon by Ołena Łucyszyna in "Classical Sāmkhya on the Authorship of the Vedas" (2012: 460-61). In that article, she quoted and considered the Yuktidipikā definition of authoritative verbal testimony (âpta-vacana) in which the Yuktidipika proclaims the idea that the Vedas are authorless. All passages of the Yuktidipikā in which its still unidentified composer expresses his view that the Vedas have no author are cited in Hayato Kondō's article, "Reinterpretation of Tradition and Transmission: Aptavacana in the Yuktidīpikā" (2012-13: 142-43). In another article, entitled "Classical Sāmkhya on the Relationship Between a Word and Its Meaning," Łucyszyna (2016: 310-15) analyzes two Yuktidīpikā passages from which we learn that the relationship between a word and its meaning is established by convention. In fact, these two passages provide indirect evidence that the Yuktidipikākāra accepted the opposite view, namely, that the Vedas have an author. However, I have not discovered a separate and comprehensive study of the Yuktidipik $\bar{a}$ view on the origin of the Vedas which takes into account all Yuktidīpikā evidence on the issue. In this article, I will undertake such a systematic study.

\footnotetext{
${ }^{1}$ The extant classical Sāṃkhya texts comprise the Sāmphyakārikā (ca. 350-450 CE) by İ́sarakṛ̣na and the following eight commentaries on it: the commentary that survived in the Chinese translation of Paramārtha (composed around $500 \mathrm{CE}$; translated into Chinese by Paramārtha between $557 \mathrm{CE}$ and $569 \mathrm{CE}$ ); the Säṃkhyavrtti (ca. 500-600 CE); the Sāmkhyasaptativrtti (ca. 500-600 CE); the Sāṃkhyakārikāahāssya (or the Gaudapādabhāsya; ca. 500-600 CE) by Gaudapāda; the Yuktidīpika (ca. 600-700 CE); the Jayamañgalā (ca. $700 \mathrm{CE}$ or later); the Mātharavrtti (ca. $800 \mathrm{CE}$ or later) by Māțhara; and the Sämkhyatattvakaumudī (ca. $841 \mathrm{CE}$ or $c a .976 \mathrm{CE}$ ) by Vācaspati Miśra. The dates and chronological order of Sāmkhya texts mentioned in this article are given according to Larson (1987: 15-18, 19-22). On the date of the Yuktidīpikā, see also the valuable observations of Mejor (2004). According to the recent and thorough research of Acharya (2006: xxviii), Vācaspati Miśra, the author of the last commentary of classical Sāṃkhya, flourished between 950 and $1000 \mathrm{CE}$.

${ }^{2}$ In the earlier texts. See Nyāyasūtras together with Vātsyāyana's Nyāyabhāṣya 1.1.7-8 and 2.1.68; Vaiśeșikasūtras $_{1}$ 6.1.1-2.

${ }^{3}$ In the later texts. See, for example, Candrānanda's Vaiśeșikasūtravrtti 6.1.2; Vyomaśiva's Vyomavatī (Varadachari 1977a: 429, 447); Vācaspati Miśra's Nyāyavārttikatātparyațīā 2.1.68; Udayana's Ätmatattvaviveka (Varadachari 1977b: 555-56); Udayana's Nyāyakusumāñjali (Potter and Bhattacharya 1977: 569, 588); Śankara Miśra's Upaskāra 1.1.3; and Annambhața's Tarkasamgraha and its autocommentary Tarkadīpika 62 .
} 


\section{Two Opposite Views on the Origin of the Vedas}

\section{View One}

The first of these opposite views on the origin of the Vedas is that the authorless but noneternal Vedas evolve from prakrti (primordial matter) at the beginning of a kalpa (a cycle of existence of the world). The evidence that the Yuktidipika supported the idea that the Vedas are authorless is provided in Yuktidipika 2 and 5. In the commentary on the fifth verse $(k \bar{a} r i k \bar{a})$ of the Sāmkhyakārikā, while explaining İ́svarakrșṇa's definition of authoritative verbal testimony (âpta-vacana), the Yuktidipikā says the Vedas are "not preceded by the intellect/thought of a purușa" (a-purușa-buddhi-pürvaka), ${ }^{4}$ which means that the Vedas were not consciously composed by an author, either human or divine. In this passage, the Yuktidīpika draws a distinction between the Vedas, being independent of any author and thus having an unquestionable authority, and the verbal testimony whose validity is based on the authority of its authors. ${ }^{5}$ It is worth noting that in the same sentence in which the Vedas are called a-purușa-buddhi-pūrvaka, they are also characterized as "independent" (sva-tantra), "conducing to the highest good of a man" (puruṣa-niḥśreyasa-artham pravartamāna), and "pramāṇa which cannot be put into doubt" (niḥsamśayam pramānam). In this context, the Vedas being "independent" (sva-tantra) can mean that they are independent of any author or that their scope of validity is independent (of the scopes of the two other Sāmkhya pramannas-perception and inference), or both. All of these characteristics of the Vedas, appearing together in one sentence of the Yuktidipikāa, were applied to the Vedas by Mīmāmsāa and express ideas developed first of all by this darśana. These characteristics are indicative of the influence of Mīmāmsā.

There is one more passage in the Yuktidipikā in which the idea that the Vedas are authorless is formulated directly by the Sāmkhya proponent. In the commentary on the second $k \bar{a} r i k \bar{a}$, the Sāmkhya proponent describes the Vedas in exactly the same manner as the passage of the commentary on the fifth $k \bar{a} r i k \bar{a}$ that I mentioned above. He characterizes them as "not preceded by the intellect of a puruṣa" (a-purușabuddhi-pürvaka), "independent" (sva-tantra), and "conducing to the highest good of a man" (purusa-nihśreyasa-artham pravartamāna). ${ }^{6}$ In the same passage, the Sāmkhya proponent also expresses the idea that the Vedas are authorless in an indirect way. He contrasts "the sentences of the Vedas" (veda-vākya), which cannot be put into doubt, with the "sentences composed by men" (pauruṣeya-vākya), which

\footnotetext{
${ }^{4}$ Compare Vaiśeșikasūtras 6.1.1: "In the Veda, composing sentences is preceded by the intellect/thought" (buddhipūrvā vākyakrtir vede II).

5 Yuktidīpikā1998: 87.3-13. (Numbers refer to Wezler and Motegi's 1998 critical edition, which is cited by page(s) and line(s); thus, 40.10-12 means page 40, lines 10-12.) For the translation and analysis of the Yuktidīpikā commentary on the definition of authoritative verbal testimony, see Łucyszyna 2012: 460-61.

6 Yuktidīpikā1998: 39.18-19.
} 
can convey not only truth but also untruth, thus suggesting that the Vedas have no author. $^{7}$

The Yuktidīpikā is the first text in classical Sāmkhya to state directly that the Vedas have no author. In most of the classical Sāmkhya commentaries that preceded the Yuktidīpikā, that is, the Sāmkhyavṛtti, Sāṃkhyasaptativrtti, and Gauḍapādabhāṣya, as well as in the Mâtharavrtti, which was composed later than the Yuktidīpikā, it is suggested that the Vedas are authorless, but this idea was not explicitly formulated in these commentaries. ${ }^{8}$ In classical Sāmkhya, the idea of the authorless Vedas, which has become the "official" Sāmkhya standpoint on the authorship of the Vedas, is directly stated also in Vācaspati Miśra's Sāmkhyatattvakaumud̄̄, the last classical Sāmkhya commentary. ${ }^{9}$ It is worth mentioning that the Sāmkhyasūtras (ca. 1400-1500 CE) and Aniruddha's commentary on them called Sāmkhyasūtravrtti (ca. 1400-1500 CE), important postclassical Sāmkhya texts that aimed to revive Sāmkhya after a long period of stagnation, not only proclaim that the Vedas have no author, but also present a polemic defending the conception of the authorless Vedas. ${ }^{10}$

If the Vedas are not composed by any author, then how do they come into existence? The Yuktidīpikā does not explain how this may happen. Since, according to Sāmkhya, every entity except puruṣa and prakrti is a noneternal product of prakrti, which merges into it during a pralaya (a cosmic dissolution), losing its own identity and distinction from prakrti, the Vedas, too, must be a noneternal product of prakrti. The authorless Vedas must evolve from prakrti at the beginning of a kalpa and be destroyed at its end. Such a conception of the origin of the Vedas is formulated explicitly in the Sāmphyyasütras and Sāmkhyasūtravritti. According to these key postclassical Sāmkhya texts, the authorless but noneternal Vedas evolve from prakrti without the conscious effort of any author at the beginning of each cycle of the world's existence. ${ }^{11}$

\section{View Two}

The second Yuktidipika view on the origin of the Vedas is that Kapila is the author of the highest teaching of the Vedas. This view, unlike the view that the Vedas have no author, is expressed only indirectly. It is evidenced by the introduction to the Yuktidipikā, where it is said that Kapila, whom Sāmkhya regards as its founder, creates names for the Sāṃkhya tattvas ("entities," the basic structural principles of

\footnotetext{
7 Yuktidipikā1998: 40.10-12. The Vedas are described in the same manner in the statement of the opponent, an adherer of Mīmāmsā: in the commentary on the second kārikā, he says that the Vedas, which are "not preceded by the intellect of a purușa" (a-purușa-buddhi-pürvaka) and "independent" (svatantra), "conduce to the highest good of a man" (puruṣa-nihśreyasa-artham pravartate) (Yuktidīpikā1998: 32.13-14).

${ }^{8}$ See Sāṃkhyavṛtti, Sāṃkhyasaptativṛtti, Gaudapādabhāṣya, and Mātharavṛtti 5.

${ }^{9}$ See Sāmkhyatattvakaumudī 2 and 5. The relevant passages of the Säṃkhyavṛtti, Sāṃhyasaptativṛtti, Gauḍapādabhāṣya, Mātharavṛtti, and Sāmkhyatattvakaumudī are considered in Łucyszyna 2012.

10 See Sāṃkhyasūtras and Sāṃkyasūtravrtti 5.41-50.

11 See Sāṃkhyasūtras and Sāṃkyasūtraṿtti 5.45-50.
} 
reality) on the basis of direct insight into the nature of all of them. ${ }^{12}$ According to the commentary on the second kārikāa, the Sāmkhya teaching of liberation through knowledge is identical with the highest teaching of the Vedas presented in the Upanișads. Therefore, the Sāmkhya terms created by Kapila are the basic Vedic terms. The twenty-five tattvas of the Sāmphya system, whose own nature (svarüpa) is grasped by Kapila through the seer's cognition (ärșeṇa jũānena), ${ }^{13}$ constitute everything that exists. Kapila's perfect knowledge of the path of liberation and the distinction between prakrti with its products and purusa, is, unlike the knowledge possessed by other creatures, inborn (sāmsiddhika), not acquired (Yuktidīpikā 4, ${ }^{14}$ $43,{ }^{15}$ and $\left.69^{16}\right)$. He is also described as "born at the beginning of the world" (viśvaagra-ja) (Yuktidipikā $1^{17}$ and $69^{18}$ ). ${ }^{19}$ From all this it follows that the omniscient Kapila, appearing at the beginning of a kalpa, creates the primary linguistic convention and Sāmkhya doctrine, the latter being identical with the quintessence of the Vedas set forth in the Upanișads. In the introduction to the Yuktidipikā, Kapila's role is similar to the role of Íśvara in Nyāya-Vaiśeșika, who creates names and the Vedas at the beginning of a kalpa.

The view that the Vedas have an author is confirmed by the commentary on the sixth kārikā, where the Sāmkhya proponent argues that the relationship between a word and its meaning is not natural but is established by convention. The assumption that the origin of all words is conventional leads to the conclusion that no text can arise in any other way than by the conscious effort of some author who knows the convention.

The passage of Yuktidipika 6 in which the author rejects the view that words have a natural and inseparable connection with their meanings is a part of the Yuktidipikā's extensive polemics in which the author argues that authoritative verbal testimony (āpta-vacana, śabda) cannot be reduced to inference (anumāna). ${ }^{20}$ I shall cite the whole passage: ${ }^{21}$

\footnotetext{
12 Yuktidipikā1998: 7.16-27. This passage drew the attention of Bronkhorst (2011: 5-6) and Kimball (2011: 177). For the translation and a detailed analysis of the whole passage, see Łucyszyna 2016: 31014.

13 Yuktidīpikā1998: 7.23.

14 Yuktidīpikā1998: 67.20-68.2, 75.19-24.

15 Yuktidīpikā1998: 233.31-234.9.

16 Yuktidīpikā1998: 267.13.

17 Yuktidīpikā1998: 8.20.

18 Yuktidīpikā1998: 267.14.

19 According to the classical Sāmkhya commentaries, Kapila appears at the beginning of a kalpa, endowed with the perfect knowledge of the twenty-five tattvas (see the commentary that survived in the Chinese translation of Paramārtha, Sāṃkhyavṛtti, Sāṃkhyasaptativrtti, Gaudapādabhāșya, Māṭaravṛtti 1, and all the extant classical commentaries on kārikā 43). This knowledge is an inseparable part of his nature, which distinguishes Kapila from other creatures (see the commentaries on Sämkhyakārikā 43).

20 Yuktidīpikā1998: 100.10-105.9.

21 This passage was briefly analyzed in Łucyszyna 2016: 315.
} 
Moreover, [a word (śabda) is not an inferential sign (linga)] because of the change. ${ }^{22}$ An [inferential] sign does not change [its connection to a particular sign bearer (lingin)] at some other place, but the change is observed in the case of a word. The very same word at some other place [or some other time] $]^{23}$ does not convey its meaning, but expresses other meaning. [You can argue], "It is because of not knowing the relationship [between the word and its meaning]. It may be so: other [that is, the genuine] relationship [between the word and its meaning] is not comprehended at another place; that is why there is the [seeming] change of the word meaning." ${ }^{24}$ This is irrelevant because of the difference of an [inferential] sign [from a word]. [It is] not [the case] that when a perceptible (pratyakșäbhimata) [inferential] sign bearer (lingin), such as cow, is perceived, [its inferential] sign (linga) [such as dewlap located on it] is not perceived. But the word ["cow"] is not perceived on the cow which is being perceived. ${ }^{25}$

Moreover, because of the restriction to a [particular] place. It is not observed that an [inferential] sign has a restriction to a [particular] place, but in the case of a word, there is a restriction to a [particular] place. For instance, [the verb] śavati is used [in the sense of] "action of going" only among the people of Kāmboja; ramhati [is used in the same sense] among easterners. In a like manner, [the word] dāti is used for a sickle <among easterners ${ }^{26}{ }^{2}$ [but] dātra [is used for it] among northerners (cf. Mahābhāssya 1.9.25ff.) [and] not anywhere else. Therefore, a word is not an [inferential] sign.

Moreover, because of the use in accordance with the wish (ișta) [of a speaker]. An [inferential] sign is natural (svābhāvika): it is not possible to draw smoke away from fire and place it in water, air, sky, or anywhere else. But a word is used wherever a speaker intends (abhiprāya) [to use it]. For

\footnotetext{
${ }^{22}$ Boldface type is used by the editors Wezler and Motegi to highlight värttikas. They distinguish two levels of the text of the Yuktidīpikā, which function as integral parts of the same whole and probably belong to the same author: that of the vārttika and that of the bhäsya.

${ }^{23}$ According to the editors Wezler and Motegi, the text [käläntare tu], bracketed by them and translated by me as "[or some other time]," is to be deleted.

${ }^{24}$ Instead of sambandhāntaram deśäntare 'nupalakșitam, one of the manuscripts used by Wezler and Motegi has sambandho deśāntare 'nupalakșitas ("[the genuine] relationship [between the word and its meaning] is not comprehended at another place"), which is probably a better reading (Yuktidīpikā1998: 101n15-16).

${ }^{25}$ According to the Sāmkhyakārikā, Sāṃkhya inference (anumāna) has two terms: an inferential sign (linga) and an inferential sign bearer (lingin). Lingin is an object to be proved by inference (see Sämkhyakārikā 5). This inference is different from the standard Indian inference (developed by the Buddhist and Nyāya logicians) with three terms: (1) inferential sign (linga)/reason (hetu) - the property being an inferential sign; (2) subject of inference (paksa) - a bearer of two properties: the inferential sign (linga) and the property to be proved (sädhya); and (3) that which is to be proved (sädhya) - the property to be proved by inference. The Yuktidīikika does not draw a distinction between pakșa and sādhya. Harzer rightly observes, "[T]he cow as a lingin may refer to both, the pakșa and the sādhya. From the discussion one may presume that the term lingin refers to the pakșa" (2006: 119n122). The author of the Yuktidipika holds that the word "cow," unlike a dewlap, is not a property of a cow. The word "cow" and an empirical cow, unlike a dewlap and a cow, are perceived separately; therefore, they exist separately and there is no inseparable relationship (which is the ground of any inference) between them.

${ }^{26}$ Compare the passage of Mahābhāsya 1.1.1. The editors of the Yuktidīpika (Wezler and Motegi) refer to Kielhorn's edition of the Mahābhāssya revised by Abhyankar: Mahābhāsya 1962: 9.25ff. The editors use < > to mark the text they added.
} 
example, the words like vrddhi, commonly known [in the sense of] "growth of one's own body" (svāingābhyuccayā), etc., are [also] used [in the sense of] $\bar{a}$, $a i$, and $a u,{ }^{27}$ etc. (cf. Pạnini 1.1.1). Therefore, these [words] are not an [inferential] sign. [You can argue], "There is no fault [in identifying a word with an inferential sign] because a word has the capacity (śaktitva) for denoting everything." The [opponent's] view may be [as follows]: "A word has the capacity for denoting everything, and an object (artha) has the capacity to be denoted by every [word]. Their capacity is limited through the act of man (purușa-vyāpāra). ${ }^{28}$ How? 'Let this very word express this object. And let this very object be denoted by this word.' Such is the act of man. Therefore, the natural relationship (svābhāvikah sambandhah) of a word [with its meaning] is manifested by the speaker's intention (apekșā)." ${ }^{29}$ This [objection] is irrelevant. Why? Because of the undesirable conclusion [that is, the conclusion which is undesirable for the opponent] (prasanga) that [a word] is completely (sutarām) different from inference. If [you] state this, it follows that a word is completely different [from inference]. For [it is] not [the case] that as the capacity of a word denoting every object is limited through the intention of the speaker, in the same manner an [inferential] sign proving every object is separated from [any] other object through the intention of the speaker. It is not so that just as one word uttered in the world, depending on [its] use by man (purușa-viniyogāpekșa), is capable of denoting every object, in the same manner one [inferential] sign is capable of making known

\footnotetext{
27 Vrddhi is a grammatical term for the vowels $\bar{a}$, ai, and au constituting the third grade of vowel gradation.

28 Compare Kumārila Bhaț̣a’s Ślokavārttika 4.228.

29 Nakada's explanation of the opponent's view is worth quoting: "So not only the characteristic (linga)...is inherently connected (sväbhāvika) with the thing (artha) which has the characteristic but also the word (śabda) is inherently connected with its meaning (artha), therefore the word (äpta-vacana, śabda) is inference (anumāna) too" (1970-71: 995). I supplemented the quotation with the Sanskrit terms in parentheses.

30 kim cānyat $\mid$ viparyayāt | na hi lingam deśāntare viparyeti I śabdasya tu drșțo viparyayah I sa eva hi śabdo deśāntare [kālāntare tu] svārtham na pratyāyayaty arthāntarạ̣ ca praśamsati I sambandhānupalabdher iti cet I syād etat I sambandhāntaram deśāntare 'nupalakșitam | tasmāc chabdārthaviparyaya iti | etad anupapannam lingavaidharmyāt I na hi pratyakșābhimatasya lingina upalabdhau gavāder lingam nopalabhyate I śabdas tūpalabhyamāne gavādau nopalabhyate | tasmān na lingaṃ |

kim cānyat | deśaniyamāt | na hi lingasya deśaniyamo dṛștah | asti tu śabdasya deśaniyamah | tad yathā śavatir gatikarmā kāmbojeșv eva bhāṣyate I ramhatih prācyeșu tathā dātir lavanārtho 〈prācyeșu〉 dātram udīcyeșu (cf. Mbhāṣya I.9.25ff.) nānyatra | tasmān na śabdo lingam |

kim cānyat I iștato viniyogāa I svābhāvikam lingam I na hi dhūmo 'gner apakrșya śakyate 'psu vāyāv $\bar{a} k \bar{s} s$ e 'nyatra vā viniveśayitum I śabdas tu yatra yatra vaktur abhiprāyas tatra tatra viniveśyate yathā vṛddhyādayah śabdāh svāñāābhyccayādiṣu prasiddhā ādaikṣu (cf. Pān 1.1.1) viniveśyante I tasmān na te lingam I sarvābhidhānaśaktitvāc chabdasyādoṣa iti cet | syān matam | sarvābhidhānaśaktih śabdah sarvābhidheyaśaktiś cārthaḥ I tayoh purușavyāpāreṇa śaktyavacchedah kriyate I katham I ayam eva śabdo 'syārthasya pratyāyako bhavatu I ayam eva cārtho 'nena śabdenābhidhīyatām I etāvati purușavyāpārah I tasmāc chabdasya svābhāvikah sambandho vaktrapekșayā vyajyata iti I etad apy anupapannam | kasmāt I sutarām anumānād arthāntaratvaprasañā̄t | evam api kalpayitvānumānāt sutarām śabdasyārthāntaratvam āpadyate I kasmāt I na hi yathā vaktrapekșayā sarvārthasya satạ śabdasya śaktyavacchedas tathā sarvārtham lingam vaktrapekșayārthāntarād avacchidyate I yathā caikah śabdo jagaty evam uditah puruṣaviniyogāpekșạ sarvam artham abhidhātum samartho 〈na〉 tathaikam lingam kayācid yuktyā sarvārthapratyāyanasamartham I tasmān na śabdo lingam I (Yuktidīpikā1998: 101.12-103.7.)
} 
every object through some reasoning. Therefore, a word is not an [inferential] sign. 30

In this passage, the author of the Yuktidipikā contrasts a word (śabda) with an inferential sign (linga). An inferential sign, which he characterizes as "natural" (svābhāvika), is naturally (inherently, by its nature) and inseparably connected to the sign bearer (lingin), that is, to the object to be proved by this sign. In illustrating the relationship between an inferential sign and the object to be proved by it, the author of the Yuktidipikā gives the example of smoke and fire. Smoke, which is an inferential sign of fire, is inseparably connected to fire: it is impossible to pull smoke out of fire and locate it in water, air, sky, or any other place.

Unlike the relationship between linga and lingin, the relationship between a word (śabda) and its meaning (artha), that is, the object denoted by it, is not inseparable. The Sāmkhya proponent, substantiating the difference between a word and an inferential sign, gives three arguments to demonstrate that the relationship between a word and its meaning is not inseparable: (1) viparyayât ("because of the change"); (2) deśa-niyamāt ("because of the restriction to a [particular] place"); and (3) iștato viniyogāt ("because of the use in accordance with the wish [of a speaker]").

The first argument-viparyayāt ("because of the change") — is that a word can change its meaning in some other place. The Sāmkhya proponent rightly points out that the same word can have different meanings in different geographical areas. The author of the Yuktidīpika adduces the following possible objection from opponents: the meaning of a word does not change, but only seems to change; a word seems to change its meaning because people inhabiting other regions do not know its genuine meaning. The Sāmkhya proponent replies to this objection by referring to perception (pratyakșa): a word and the object denoted by it, for example, the word "cow" and an empirical cow, are often perceived separately from each other. The inseparable relationship between two things, which is the ground of inference, is always established by perception. In the case of a word and its meaning, perception proves that there is no inseparable relationship between them. Therefore, there is no reason to assume that a word does not change its meaning.

The second argument-deśa-niyamät ("because of the restriction to a [particular] place")—is that a word, unlike an inferential sign, is local. The inseparable relationship between linga and lingin is a universal relationship: smoke is connected to fire in every geographical region and in every historical period. The author of the Yuktidīpikā gives concrete examples illustrating the local character of different words. For example, the word śavati denotes the action of going only among the people of Kāmboja, and the word dātra is used for a sickle only by northerners. In some regions, these words are not related to their meanings; therefore, the relationship between a word and its meaning is not inseparable.

The third argument-istato viniyogat ("because of the use in accordance with the wish [of a speaker]"-is that a word can denote every object, and its relationship with this very meaning (object) is established through its use by the speaker. To illustrate this, the author of the Yuktidipika considers the meanings of the word $v r d d h i$. The word vrddhi, commonly known in the sense of "growth of one's own body," is also used as a grammatical term for the vowels constituting the third 
(strongest) grade of vowel gradation. It seems very probable to me that the Yuktidīpikākāra chooses the technical term from Sanskrit grammar to illustrate his thought because the conventional character of many technical terms, that is, their being created by certain authors, was a well-known fact established by perception. If the conventional character of the relationship between many words and their meanings is obvious and it has always been possible to create new word-meaning relationships, then all words must be conventional in their origin.

According to the author of the Yuktidipika, the relationship between a word and its meaning is not natural and inseparable. The Yuktidīpikākāra holds that this relationship depends on the wish (ișta)/intention (abhiprāya) of the speaker. It follows from this that the Vedas, which consist of words, cannot be a naturally occurring entity, that is, an entity evolving from prakrti without the conscious effort of any author. In this passage, the Yuktidipikākāra accepts the view that all words are conventional in their origin, though he does not use the word "convention" (samaya, samketa). If all words are conventional in their origin, the Vedas, like any other text, can arise in no other way than by the conscious effort of some author (or authors) who knows the convention.

\section{Nirukta in the context of the Yuktidīpika}

Having presented the two opposite views on the origin of the Vedas, I shall now consider the Yuktidīpika passage containing the famous quotation from Yāska's (fifth century BCE) Nirukta (1.20), ${ }^{31}$ also cited in the Vrtti on Bhartrhari's (between 450 and $510 \mathrm{CE})^{32}$ Vákyapadìya (1.5). ${ }^{33}$ It may seem that by means of this quotation the author of the Yuktidipika says something about the origin of the Vedas. The quotation has drawn the special attention of many scholars, such as Wilhelm Halbfass (1991: 48n69), Albrecht Wezler (2001), Ashok Aklujkar (2009), Madhav M. Deshpande (2009: 164), and James Kimball (2016: 548), who have discussed its meaning in the context of the Nirukta, the Vākyapadīya together with its Vrtti, ${ }^{34}$ or the Yuktidīpikā. Detailed studies were undertaken by Aklujkar and Wezler. The

\footnotetext{
31 sākșātkṛtadharmāṇa rṣayo babhūvuh । te 'varebhyo 'sākșātkṛtadharmabhya upadeśena mantrān samprāduh I upadeśāya glāyanto 'vare bilmagrahaṇāyemạ̣ granthạ̣ samāmnāsiṣur vedam ca vedāngāni ca | bilmam bhilmam bhāsanam iti vā | (Nirukta1998: 41-42). The Yuktidīpikā cites this excerpt, save for the last sentence. The last sentence (explaining bilma), as Wezler (2001: 241) rightly observes, forms the basis of the statement that follows the quotation in the Yuktidipika . The quotation found in the Yuktidīpika deviates slightly from the text of the Nirukta: in the Yuktidīpikā, aparebhyah and apare (which are the forms of apara, meaning "posterior," "later," "following," "inferior," "lower," "other") appear in place of avarebhyah and avare (the forms of avara, meaning "inferior," "lower," "posterior," "later"). The same deviation occurs in the quotation appearing in the Vrtti on Bhartrhari's Vākyapadīya (see below).

32 The dates of Yāska and Bharțhari are given according to Coward and Raja (2001: 107, 121).

33 “sākșātkṛtadharmāṇa rșayo babhūvus te 'parebhyo 'sākșātkṛtadharmabhya upadeśena mantrān samprāduh upadeśāya glāyanto ’pare bilmagrahaṇāyemam granthạ̣ samāmnāsiṣur vedam vedāingāni ca | bilmạ̣ bhilmam bhāsanam vā" iti | (Vākyapadīya of Bhartṛhari1966: 24-25).

34 It looks like the question of the authorship of the Vrtti on Bhartrhari's Vākyapadīya is still open. In the Encyclopedia of Indian Philosophies, we read, "It seems likely that Bhartrhhari also composed the commentary called vṛtti on at least the first two chapters of the Trikānd $\vec{\imath}$ " (Coward and Raja 2001: 121).
} 
Nirukta is quoted in the commentary on Sämkhyakārikā 51 in the context of defining the eight attainments (siddhi, "attainment," "perfection"), after characterizing the nature of the first three of them: ūha ("reflection," "reasoning," "consideration," "comprehension"), ${ }^{35}$ śbda ("word," "utterance," "speech," "communication"), and adhyayana ("study"). ${ }^{36}$

The passage in which the author of the Yuktidipikā explains the first three siddhis and cites the Nirukta reads as follows:

Of these [the attainment] named "comprehension" ( $\bar{u} h a)$ [takes place] when one attains the desired aim by the power of discernment (vicārana) ${ }^{37}$ only, without perception (pratyakșa), inference (anumāna), and authoritative verbal testimony (ägama). This is the first attainment (siddhi) called "causing to cross [the ocean of samsāra]" (tāraka). It is called tāraka, for it causes one to cross (tārayati) the ocean of samsāra.

But when one who is obstructed in attaining [the desired aim] by himself attains [it] through the teaching (upadeśa) of a guru, this is the second attainment called "carrying across easily" (sutāra). Whence [is it called so]? Because through this they [that is, the disciples] easily cross the straits of worldly existence (bhava-samkața) even now (adyatve 'pi).

But when one who is unable to attain [the desired aim] even through another's teaching attains [it] through study (adhyayana), this is the third attainment called "causing crossing [of the ocean of samsāara]" (tārayant). It is called tārayant because the act of crossing (tārana-kriyā) [takes place] even now (adyatve 'pi), because it is unceasing (avyāvrttatva), and because it has a large scope (mahā-vișayatva). These are the three means by which living beings beginning with Brahmā attain the desired aim. And it is said: "There were seers having a direct insight into the nature [of things which is imperceptible to ordinary people] (sāksāt-krta-dharman). They handed down

\footnotetext{
35 The meaning of the term $\bar{u} h a$ in the Yuktidīpika is not clear. In the context of the passage cited below, it refers to an insight lying beyond the pramānas by which ordinary people acquire valid knowledge (pramā). In Yuktidīpikā 23, on the contrary, the commentator interprets knowledge achieved through $\bar{u} h a$ as knowledge of the distinction between gunas and puruṣa obtained through pramāna(s). He distinguishes between this kind of knowledge and liberating knowledge of the distinction between gunas and prakrti which is "produced through practice" (abhyāsa-ja). The latter kind of knowledge is the liberating direct insight described in Sāmkhyakārikā 64 (Yuktidīpikā1998: 192.7-14). For the translation and analysis of this passage, see Łucyszyna 2010: 324-28. Kimball (2016: 552-54) gives a different interpretation of this passage of Yuktidīpikā 23, but these interpretative differences need not be discussed here.

In the commentary that survived in the Chinese translation of Paramārtha, the Gaudapādabhāṣa, Mātharavṛtti, and Sāmkhyatattvakaumud̄, ūha means "reasoning," "reflection," "consideration" (in the

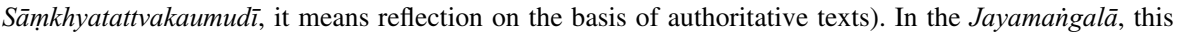
term probably has the same meaning (the Jayamaingalā passage describing $\bar{u} h a$ is difficult to understand). As it follows from the editions of the Sämkhyavrtti and Sämkhyasaptativrtti prepared by Solomon, an explanation of $\bar{u} h a$ is missing in the extant manuscripts. For the meaning of $\bar{u} h a$ in the Gaudapādabhāsya and Mātharavrtti, see Kimball 2016: 541-42.

36 The eight attainments are: ūha, śabda, adhyayana, duḥkha-vighātās trayah ("three kinds of destruction of suffering"), suhrt-prāpti ("gaining friends," "gaining [knowledge] from friend(s)"), and dāna ("giving," "donation," "charity”) (Sāmkhyakārikā 51).

37 Vicärana-in the context of the cited passage, this term can also be translated as "mental grasp" or "contemplation."
} 
mantras by teaching (upadeśa) to the later ones (apara), destitute of a direct insight into the nature [of things] (a-sākșāt-krta-dharma). The later ones, tired of [/disinclined toward] teaching, compiled this work, the Veda, and the Vedāngas for grasping a bilma (bilma-grahaṇāya)" [Nirukta 1.20]. Bilma [means] "understanding" (bhāsana); [thus] a special designation of a thorough understanding (samyak-pratibhāsa) is presented. ${ }^{38}$

My translation of this passage is for the purposes of this study, and I shall not go into its terminological intricacies or all the richness and subtleties of its meaning. I would also like to emphasize that I interpret the quotation from the Nirukta as an integral part of this Yuktidīpikā passage describing the attainments.

In the quotation from the Nirukta, it is said that seers (rsi), "having a direct insight into the nature [of things]" (sākșāt-krta-dharman), transmitted mantras by teaching (upadeśa) to "the later ones" (apara), "destitute of a direct insight into the nature [of things]" (a-sākșāt-krta-dharma), ${ }^{39}$ and that these "later ones" compiled "this work" (imam grantham), the Veda, and the Veda ancillaries (vedāinga). By "this work," Yāska meant the Nighanțu, the collection of Vedic words explained in his Nirukta.

In the context of the Yuktidipikā, scholars interpret this quotation as an illustration of either the third attainment, or the second and third attainments, or all of the first three attainments. According to Aklujkar (2009: 85), the Nirukta is cited to explain the third (adhyayana) siddhi. Wezler writes that the Nirukta is "quite evidently quoted in order to give a particularly significant example for the operation of the second and third of the siddhis" (2001: 240). Kimball holds that the Nirukta is cited "apparently to illustrate the nature of these three siddhis by relating $\bar{u} h a$ to the knowledge of the Vedic rssis who have 'the qualities [of things] placed [directly] before the eyes' (sākșātkrtadharman), and relating śabda and adhyayana to the transmission of Vedic knowledge through the guru-śisya relationship and through composed texts, respectively" (2016: 548).

The point on which the three scholars agree is that the quotation from the Nirukta functions in the Yuktidipika as an illustration of some of the siddhis, and I subscribe to their opinion. As to the question of which siddhis are exemplified by this

\footnotetext{
38 tatroho nāma yadā pratyakșānumānāgamavyatirekeṇābhipretam artham vicāraṇabalenaiva pratipadyate sādyā siddhis tārakam ity apadiśyate I tārayati samsāāārnavād iti tārakam । yadā tu svayam pratipattau pratihanyamāno gurūpadeśāt pratipadyate sā dvitīyā siddhih sutāram ity apadiśyate | katham | sukham anenādyatve 'pi bhavasamkațāt tarantīti |

yadā tv anyopadeśād apy asamarthah pratipattum adhyayanena sādhayati sā tṛtīyā siddhis tārayantam ity apadiśyate I tad etat tāraṇakriyāyā adyatve 'py avyāvṛttatvān mahāvișayatvāt tārayantam ity apadiștam | ta ete trayah sādhanopāyyā yair $\bar{a}$ brahmaṇah prāṇino 'bhipretam artham prāpnuvanti I āha ca "sākșātkṛtadharmāṇa rșayo babhūvuh । te 'parebhyo 'sākșātkṛtadharmebhya upadeśena mantrān samprāduḥ | upadeśāya glāyanto 'pare bilmagrahaṇāyemam granthạ samāmnāsișur vedam ca vedāngāni ca" (Nir. 1.20) iti | bilmam bhāsanam samyakpratibhāsāya viśișțh samketa uktaḥ | (Yuktidīpikā1998: 251.12-252.2).

39 It is not clear why the Yuktidīpikā reads asākșātkṛtadharmebhya instead of asākșātkṛtadharmabhya, deviating thus from the Nirukta (cited in footnote 31) and the Vākyapadìa's Vrtti (cited in footnote 33). Can it be a mistake that should be corrected in a critical edition? This deviation probably does not influence the meaning. For the meaning and possible translations of sākșät-krta-dharman, see Ruegg 1994; Wezler 2001: 223-30; Aklujkar 2009: 12-28.
} 
quotation, I agree with Kimball that it illustrates all of the first three siddhis. The first attainment- $\bar{u} h a$ - takes place when one achieves liberating knowledge (that is, the "seeing" [darśana] of the distinction between purusa and prakrti with its products) ${ }^{40}$ by the power of mental discernment (vicārana) which is beyond the pramānas applied by ordinary people, and this discernment corresponds to the seers' direct insight into the imperceptible reality. The second attainment-śabdaoccurs when one who is unable to come to liberating knowledge through such extraordinary mental discernment (vicāraṇa) achieves this knowledge through the upadeśa of a guru, and in the quotation from the Nirukta, "the later ones" (apara), destitute of the direct insight into the imperceptible reality, attain liberating knowledge in this very way, that is, through the upadeśa (of the seers). The third attainment-adhyayana - takes place when one who is unable to achieve liberating knowledge through another's teaching (upadeśa) achieves it through study (adhyayana), and in the Nirukta quotation, "the later ones" (apara), "tired of teaching," probably because of the limited learning capacity of those they tried to teach, compile for them the texts to study.

Hence, the first attainment characterizes the seers; the second characterizes "the later ones" taught by the seers; and the third characterizes all those for whom "the later ones" compiled the texts. In addition to these correspondences, the assumption that the Nirukta quotation illustrates all of the first three siddhis is confirmed by the following fact. The Yuktidipika author cites the Nirukta not immediately after the description of the third attainment, but after the summarizing sentence (coming after this description) in which he states that by the above three means, living beings attain their aim. ${ }^{41}$

In my opinion, it is rather unlikely that by quoting the Nirukta, the Yuktidipik $\bar{a}$ author aims to communicate something about the origin of the Vedas. Even if he touches on this issue (indirectly), it is not clear whether the primeval Veda was merely perceived by the rșis, and thus has no author, or, as in earlier NyāyaVaiśeșika, was created by them on the basis of their direct insight into the reality imperceptible to ordinary people.

Why does the author of the Yuktidīpikā choose this citation to illustrate Sāmkhya thought? I think that the inclusion of this quotation in the text of the Yuktidipika $\bar{a}$ is an element of an important project of the Yuktidīpikākāra which Shujun Motegi calls an attempt at "reconciliation with the Vedas" (2006: 54). ${ }^{42}$ This project is realized by the Yuktidipika author mainly in the commentary on the second kārikāa, in the vast polemics with Mīmāmsāa on the highest goal of man and the means of achieving it. The Yuktidīpikā is the first classical Sāmkhya text that endeavors to substantiate that the Vedas comprise not only ritual parts, but also the highest science of liberation through knowledge.

\footnotetext{
40 Yuktidīpikā1998: 253.11.

41 By this aim, liberation (kaivalya, literally "isolation [of purușa from prakrti]") is meant; see the end of the commentary on this kārikā (Yuktidīpikā1998: 253.12-13).

42 Such reconciliation was badly needed. It is difficult not to agree with Ham who writes, "The Sāmkhyas, with their critique of the Vedic cultural norm, went to an extreme and, by doing so, risked their membership in the loose association of Brahmanical intellectual circles, collectively termed "āstika'", (2016: 137).
} 
İ́varakṛ̣ṇa, in the first two kārikās of his Sāṃkhyakārikāa, along with all classical Sāṃkhya commentators explaining these kārikās, claims that the Sāmkhya means of eliminating suffering (duhkha) through the discriminative knowledge (vijñanna) of prakrti, its products, and purușa is superior to the Vedic (änuśravika) means because the Sāmkhya means lead to the complete and final elimination of suffering, whereas by performing a Vedic ritual, a human being will continue to remain in samsāra and experience suffering. This distinction between the Sāmkhya means and the Vedic means suggests that Sāmkhya and śruti conflict with one another, for none of the classical Sāmkhya authors before the author of the Yuktidipika observed that the Vedas contain more than just ritual parts. The author of the Yuktidipika-for the first time in classical Sāmkhya history-attempts to show that the Vedas comprise not only ritual parts, but also those parts that teach the path of liberation through knowledge; that according to śruti, the science of liberation through knowledge is the highest science, for it leads to the complete and final elimination of suffering; and that Sāmphya is identical with this highest science of the Vedas set forth in the Upanișads (Yuktidīpikā 2). ${ }^{43}$

The first view on the origin of the Vedas presented above, according to which the Vedas have no author, and thus possess an unquestionable authority, differing in this respect from all other kinds of authoritative verbal testimony, is, too, an integral part of this project to reconcile Sāmkhya with the Vedas. ${ }^{44}$

What characterizes the Yuktidipika passage quoting the Nirukta as a part of this project to reconcile Sāmkhya with the Vedas? The passage contains the following implications which indicate that it is a part of this project. The Vedic seers achieved liberating knowledge (of the distinction between prakrti and purusa) in the most perfect way-their attainment (siddhi) called $\bar{u} h a$ is the first, that is, the most excellent among the attainments. The Vedic seers transmitted their knowledge to other people, destitute of the capacity to achieve it through $\bar{u} h a$, and the latter ones achieved liberating knowledge thanks to the seers' upadeśa. The people taught by the Vedic seers compiled the Vedas, encompassing the science of liberation, as well as the texts explaining them, and it is now possible to achieve liberating knowledge through study of the Vedas. It follows from this passage that the Vedas contain the highest science of liberation through the discriminative knowledge of prakrti and purușa, and therefore should be respected, and that Sāmkhya is a Vedic doctrine.

When Yāska, cited in the Yuktidīpikā, referred to "this work" (imam grantham), he meant the Nighantu commented on in his Nirukta, but the author of the Yuktidīpikā could have alluded to the Sämkhyakärikā commented on in his Yuktidīpika and suggested in this way that both the Sämkhyakārika and Yuktidīpikā were works explaining the Vedas.

I consider the passage quoting the Nirukta to be a part of the Yuktidipikä's project to reconcile Sāmkhya with the Vedas, for this passage implies that the Vedas teach the highest science of liberation through knowledge. It is worth noting, however,

\footnotetext{
43 Yuktidīpikā1998: 35.9-54.16.

44 To quote Motegi's opinion about the Yuktidīpikā interpretation of the Sāmkhyakārikā (5) definition of authoritative verbal testimony (apta-vacana): "It is to be surmised that by means of this interpretation the author of the Yuktidipika sought to differentiate the Vedas from all other reliable sources and show that they are exceptional in their reliability" (2006: 53).
} 
that Kapila's status in the Yuktidīpika is higher than the status of the Vedic rșis mentioned in this passage. The seers attain liberating knowledge (through $\bar{u} h a$ ), whereas Kapila does not need to acquire it, for it is inborn (sāmsiddhika) to him (Yuktidīpikā $4^{45}, 43^{46}$, and $69^{47}$ ). In the commentary on Sāmkhyakārikā 43, the Yuktidīpikākāra says directly that $\bar{u} h a$ does not take place in the case of Kapila, as his perfect knowledge originates together with his subtle and physical body. ${ }^{48}$

\section{Conclusion}

The author of the Yuktidipika wavers between at least two different views on the origin of the Vedas. The first view is that the authorless but noneternal Vedas evolve from prakrti at the beginning of a kalpa and merge into prakrti during a pralaya. The Yuktidipikā is the first classical Sāmkhya text to state directly that the Vedas have no author and to distinguish clearly between the Vedas, being independent of any author, and thus having the highest, unquestionable authority, and verbal testimony whose authority depends on the authority of its author. The ideas and terminology of the passages in which the Yuktidipikākāra affirms the authorlessness of the Vedas confirm that he was influenced by Mīmāmsā.

The second and opposite Yuktidipika view on the origin of the Vedas is that Kapila is the author of the highest teaching of the Vedas set forth in the Upanișads. This view is expressed only indirectly. Omniscient Kapila, appearing at the beginning of a kalpa, creates the primary linguistic convention and Sāmkhya doctrine, the latter being identical with the highest teaching of the Vedas, and his role is similar to the role of Íśvara in Nyāya-Vaiśeșika, who creates names and the Vedas at the beginning of creation.

The Yuktidīpikā contains the famous citation from Yāska's Nirukta (1.20), and it may seem that by means of this quotation, the author of the Yuktidipika communicates ideas about the origin of the Vedas. The Nirukta is cited in the context of defining the eight attainments (siddhi), and the citation functions as an illustration of the first three of them. It is rather unlikely that by quoting the Nirukta, the Yuktidīpikākāra intends to say something about the origin of the Vedas. Even if he touches on this issue indirectly, it is not clear from this passage whether the primeval Veda was perceived by the seers, and thus has no author, or, as in the earlier Nyāya-Vaiśeșika, was created by them on the basis of their insight into imperceptible reality. The Yuktidīpika passage containing the quotation from the Nirukta can hardly be regarded as supporting either of the two views presented above.

Why does the Yuktidīpikākāra select this quotation to illustrate Sāṃkhya thought? The inclusion of this citation in the text of the Yuktidipika can be explained as a part of his important and pioneering (that is, new to Sāṃkhya) project to

\footnotetext{
45 Yuktidīpikā1998: 67.20-68.2, 75.19-24.

46 Yuktidīpikā1998: 233.31-234.9.

47 Yuktidīpikā1998: 267.13

48 Yuktidīpikā1998: 233.31-234.4. On this passage, see Kimball 2016: 550.
} 
reconcile Sāmkhya with the Vedas. The passage quoting the Nirukta implies that the Vedas teach the highest science of liberation through the discriminative knowledge of prakrti with its products and purușa, and therefore should be revered, and that Sāmkhya is a Vedic doctrine. The first view on the origin of the Vedas considered above, too, is a part of this project to reconcile Sāmkhya with the Vedas.

Which of these opposite views on the origin of the Vedas accords with Sāmkhya doctrine? The first view, based on the idea of the authorless Vedas and influenced by Mìmāmsā, presupposes that not only the Vedas, but also the words and linguistic sounds that constitute the Vedas evolve from prakrti at the beginning of a kalpa and exist (actually, not potentially) until the next pralaya. This view is not in agreement with the Sāṃkhya system. For Sāṃkhya, each particular sound (linguistic as well as nonlinguistic) is a unique and transient modification (vikāra) or manifestation (abhivyakti) of prakrti that comes into actual existence only once; it is not something that can be manifested many times-by different speakers (or other causes), at different times, and in different places. ${ }^{49}$ The second view, according to which the Vedas have an author, is grounded on the assumption that the origin of all words is conventional. I think that this view is compatible with the Sāmkhya system. However, in accepting it, Sāmkhya had to develop a theory of universals-not only of universals of things, but also of universals of words and linguistic sounds-to explain how language learning and communication are possible. It is difficult to find a place for a universal as a separate ontological category in the Sāṃkhya system, but Sāmkhya could admit universals as general notions. ${ }^{50}$

Why does the Yuktidīpikā — and Sāmkhya in general-accept as its "official" standpoint that view on the origin of the Vedas which is in conflict with the Sāmkhya doctrine, namely, the first view, which holds that the Vedas have no author, evolving from prakrti spontaneously? The second Yuktidipikā view, which holds that Kapila is the author of the highest teaching of the Vedas, implies that the status of Sāmkhya is not lower and may even be higher than the status of the Vedas. Such a view, if stated directly, could hardly enhance the reputation of Sāmkhya as a school of philosophy that recognizes the authority of the Vedas. The first view, on the contrary, maintains the highest and most distinguished status of the Vedas, and therefore is the proper choice to secure a place for Sāmkhya in Indian intellectual history. This is why the author of the Yuktidipika affirms the first view as the

\footnotetext{
49 See Łucyszyna 2016: 304-5, 316-19.

50 Indian philosophers were aware that the word-meaning relationship making language learning and communication possible cannot be based on word and meaning understood as unique and transient entities. For this reason, the Naiyāyikas and Vaiśeșikas, rejecting the Mīmāṃsā conception of everlasting words, introduced the conception of universals of words. Pind (1991) holds that the Buddhist philosopher Dignāga, too, was aware of the problem. Pind shows that according to Dignāga, the relationship between a word and its meaning is the relationship between a word universal (śabda-sāmānya) and a meaning universal (artha-sāmānya), that is, the relationship between types, not between "their individual realizations (artha-śabda-viśeșa)," which "are claimed not to constitute such a relation because they have not previously been observed together" (1991: 270). For Dignāga, unlike for the Naiyāyikas and Vaiśeșikas, a universal is not something existing independently of our minds. Classical Sāmkhya did not develop a theory of universals. It also did not develop a theory of word meaning. On word meaning and universals in classical Sāṃkhya, see Łucyszyna 2016: 305-9.
} 
"official" standpoint of the Sāṃhya darśana, including it in his pioneering project to reconcile Sāmkhya with the Vedas.

Acknowledgements I am deeply grateful to Sushil Mittal, the editor of this Journal, for his immense support and encouragement during the whole process of preparing this article for publication. His guidance and brilliant and painstaking editing helped to avoid essential inaccuracies and enhance the quality of this paper. His contribution to its betterment is difficult to overestimate. I thank Hyoung Seok Ham, Edeltraud Harzer, and Noémie Verdon for their helpful comments and encouragement to continue working on the Yuktidipikā. I am much obliged to the reviewers for their thorough analysis of my paper and insightful, precise, and valuable suggestions on how to improve the text. My sincere thanks to Catherine Davis for carefully editing the manuscript and significantly improving its style. This study was generously supported by the National Science Centre, Poland, project \# 2017/01/X/HS1/01469.

Open Access This article is licensed under a Creative Commons Attribution 4.0 International License, which permits use, sharing, adaptation, distribution and reproduction in any medium or format, as long as you give appropriate credit to the original author(s) and the source, provide a link to the Creative Commons licence, and indicate if changes were made. The images or other third party material in this article are included in the article's Creative Commons licence, unless indicated otherwise in a credit line to the material. If material is not included in the article's Creative Commons licence and your intended use is not permitted by statutory regulation or exceeds the permitted use, you will need to obtain permission directly from the copyright holder. To view a copy of this licence, visit http:// creativecommons.org/licenses/by/4.0/.

\section{References}

\section{Sāṃkya Sanskrit Texts}

Gaựapādabhāṣya. See Sāṃkhyakārikābhāṣya.

Jayamaṅgalā. 1970 [1922]. Sāṃkhyakārikā of Śrīmad İśvarakrsṣna with the Māṭaravrtti of Mātharācārya and the Jayamañgalā of Śrì Śañkara (eds. Viṣnuprasāda Śarman [Mātharavrtti] and Satkāriśarman Vaṅīya [Jayamañgalā]). Varanasi: Chowkhamba Sanskrit Series Office.

Māṭharavrtti. See Jayamañgalā.

Paramārtha (the commentary that survived in the Chinese translation of Paramārtha). 1904. "La Sāṃkhyakārikā étudiée à la lumière de sa version chinoise (II) par M. J. Takakusu. Traité sur les «Septante d'or » (Suvarṇasaptati) ou Traité sur la philosophie Sāṃkhya (Sāṃkhyaçāstra) traduit par Paramārtha." Bulletin de l'Ecole Française d'Extrême-Orient 4: 978-1064.

Paramārtha (the commentary that survived in the Chinese translation of Paramārtha). 1944. Suvarnasaptati Śāstra: Sānkkhya-Kārikā-Saptati of İ́svara-Krsṣna with a Commentary. Reconstructed into Sanskrit from the Chinese Translation of Paramārtha and Edited with English Notes, Introduction and Appendices by N. Aiyaswami Sastri. Tirupati: Tirumalai-Tirupati Devasthanams Press.

Sāṃkhyakārikā. 1998. Íśvarakṛṣna: Sāṃkhyakārikā (ed. Ferenc Ruzsa). Available at: http://gretil.sub.unigoettingen.de/gretil/1_sanskr/6_sastra/3_phil/samkhya/isvskaru.htm (accessed December 5, 2011).

Sāṃhyakārikābhāṣya. 1883. The Sāṅkhya Kārikā with an Exposition Called Candrikā by Nārāyana Tìrtha, and Gaudapādācārya's Commentary (ed. Becanarama Tripathi). Benares: Messrs. Braj B. Das and Co.

Sāṃkhyasaptativṛtti. 1973. Sāṃkhya-Saptati-Vṛtti $\left(V_{l}\right)$ (ed. Esther A. Solomon). Ahmedabad: Gujarat University.

Sāṃkhyasūtras and Sāṃkhyasūtravrtti. 1888. Aniruddha's Commentary and the Original Parts of the Vedāntin Mahādeva's Commentary to the Sāmkhya Sūtras (ed. Richard Garbe). Calcutta: Asiatic Society of Bengal.

Sāṃhyatattvakaumudī. 1871. Sankhyatatwa Koumudi by Bachaspati Misra (ed. Taranatha Tarkavachaspati). Calcutta: Sucharu Press.

Sāṃkhyavṛtti. 1973. Sāṃkhya-Vṛtti (V2) (ed. Esther A. Solomon). Ahmedabad: Gujarat University.

Yuktidīpikā. 1998. Yuktidīpikā: The Most Significant Commentary on the Sāmkhyakārikā (eds. Albrecht Wezler and Shujun Motegi). Volume 1. Stuttgart: Franz Steiner Verlag. 


\section{Other Sanskrit Texts}

Mahābhāṣya. 1962 [1880]. The Vyākarana-Mahābhāṣya of Patañjali (ed. Franz Kielhorn; third edition revised by Kashinath Vasudev Abhyankar). Volume 1. Poona: Bhandarkar Oriental Research Institute.

Nirukta. 1998 [1920-27]. The Nighanțu and the Nirukta: The Oldest Indian Treatise on Etymology, Philology, and Semantics (ed. and trans. Lakshman Sarup). Delhi: Motilal Banarsidass.

Nyāyasūtras, Nyāyabhāṣya, Nyāyavārttika, and Nyāyavārttikatātparyațīā. 1936-1944. Nyāyadarśanam: With Vātsyāyana's Bhāṣya, Uddyotakara’s Vārttika, Vācaspati Miśra’s Tātparyațīkā and Viśvanātha's Vrtti (eds. Taranatha Nyaya-Tarkatirtha [chapter I, section I] and Amarendramohan Tarkatirtha and Hemantakumar Tarkatirtha [chapters I-ii-V]). 2 volumes. Calcutta: Metropolitan.

Ślokavārttika. 1978. Ślokavārttika of Śrī Kumārila Bhațta with the Commentary Nyāyaratnākara of Śrī Pārthasārathi Miśra (ed. Dwarikadas Shastri). Varanasi: Tara Publications.

Tarkasamgraha and Tarkadīpikā. 1930 [1897]. Tarka-Samgraha of Annambhatta with the Author's Own Dīpikā, and Govardhana's Nyāya-Bodhinī (ed. Yashwant Vasudev Athalye; trans. [of the TarkaSamgraha] Mahadev Rajaram Bodas). Poona: Bhandarkar Oriental Research Institute.

Upaskāra. See Vaiśeșikasūtras 2 .

Vaiśeșikasūtras $_{1}$ (the recension of the Vaiśeșikasūtras found in the commentary Vaiśeșikasūtravrtti by Candrānanda). 1961. Vaiśeșikasūtra of Kaṇāda, with the Commentary of Candrānanda (ed. Muni Jambuvijaya). Baroda: Oriental Institute.

Vaiśeșikasūtras $_{2}$ (the recension of the Vaiśeșikasūtras found in the commentary Upaskāra by Śankara Miśra). 1861. The Vaiśeșika Darśana, with the Commentaries of Śankara Miśra and Jayanārāyana Tarka Pañcānana (ed. Jayanarayana Tarka Panchanana). Calcutta: Asiatic Society of Bengal.

Vaiśeșikasūtravṛtti. SeeVaiśeșikasūtras ${ }_{1}$.

Vākyapadīya (and the Vrtti on it). 1966. Vākyapadīya of Bhartṛhari with the Commentaries Vrtti and Paddhati of Vrșabhadeva: Kāṇda I (ed. K. A. Subramania Iyer). Poona: Deccan College Postgraduate and Research Institute.

\section{Secondary Literature}

Acharya, Diwakar. 2006. Vācaspatimiśra's Tattvasamīkșā: The Earliest Commentary on Maṇdanamiśra’s Brahmasiddhi. Critically Edited with an Introduction and Critical Notes. Stuttgart: Franz Steiner Verlag.

Aklujkar, Ashok. 2009. "Veda Revelation According to Bhartr-hari." In Mithilesh Chaturvedi, ed., Bhartrhari: Language, Thought and Reality (Proceedings of the International Seminar, Delhi, December 12-14, 2003), 1-97. Delhi: Motilal Banarsidass.

Bronkhorst, Johannes. 2011 [1999]. Language and Reality: On an Episode in Indian Thought (trans. Michael S. Allen and Rajam Raghunathan). Leiden: Brill.

Coward, Harold G. and K. Kunjunni Raja, eds. 2001 [1990]. Encyclopedia of Indian Philosophies. Volume 5: The Philosophy of the Grammarians. Delhi: Motilal Banarsidass.

Deshpande, Madhav M. 2009. "Revisiting the Notion of Śișta in Bhartṛhari.” In Mithilesh Chaturvedi, ed., Bhartrhari: Language, Thought and Reality (Proceedings of the International Seminar, Delhi, December 12-14, 2003), 163-75. Delhi: Motilal Banarsidass.

Halbfass, Wilhelm. 1991. Tradition and Reflection: Explorations in Indian Thought. Albany: SUNY Press.

Ham, Hyoung Seok. 2016. "Buddhist Critiques of the Veda and Vedic Sacrifice: A Study of Bhāviveka's Mīmāṃsā Chapter of the Madhyamakahrdayakārikā and Tarkajvālā.” Ph.D. dissertation, University of Michigan, Ann Arbor.

Harzer, Edeltraud. 2006. The Yuktidīpikā: A Reconstruction of Sänikhya Methods of Knowing. Aachen: Shaker Verlag.

Kimball, James. 2011. "The Soteriological Role of the Rși Kapila in the Yuktidipikīa: The Production and Transmission of Liberating Knowledge in Classical Sāmkhya." Ph.D. dissertation, School of Oriental and African Studies, University of London.

Kimball, James. 2016. "The Relationship Between the Bhāvas and the Pratyayasarga in Classical Sāṃhya." Journal of Indian Philosophy 44, 3: 537-55. 
Kondō, Hayato. 2012-13. "Reinterpretation of Tradition and Transmission: Aptavacana in the Yuktidīpikā." Journal of Indological Studies 24-25: 137-68.

Larson, Gerald James. 1987. "The History and Literature of Sāṃkhya.” In Gerald James Larson and Ram Shankar Bhattacharya, eds., Encyclopedia of Indian Philosophies. Volume 4: Sāmkhya: A Dualist Tradition in Indian Philosophy, 3-41. Delhi: Motilal Banarsidass.

Łucyszyna, Ołena. 2010. "Poznanie prawdziwe a poznanie wyzwalające w sāmkhyi (na podstawie analizy klasycznych komentarzy do Sāmkhya-kāriki 23).” Ruch Filozoficzny 67, 2: 319-34.

Łucyszyna, Ołena [Lutsyshyna, Olena]. 2012. "Classical Sāmkhya on the Authorship of the Vedas." Journal of Indian Philosophy 40, 4: 453-67.

Łucyszyna, Ołena. 2016. "Classical Sāmkhya on the Relationship Between a Word and Its Meaning." Journal of Indian Philosophy 44, 2: 303-23.

Mejor, Marek. 2004. "Some Observations on the Date of the Yukti-dīpikā (Apropos of the New Edition)." In Piotr Balcerowicz and Marek Mejor, eds., Essays in Indian Philosophy, Religion and Literature, 399-433. Delhi: Motilal Banarsidass.

Motegi, Shujun. 2006. "Śabda in the Yuktidīpikā." Acta Asiatica 90: 39-54.

Nakada, Naomichi. 1970-71. "Word and Inference in the Yuktidīpikā: Part II." Journal of Indian and Buddhist Studies 19, 2: 1000-994.

Pind, Ole Holten. 1991. "Dignāga on Śabdasāmānya and Śabdaviśeșa." In Ernst Steinkellner, ed., Studies in the Buddhist Epistemological Tradition: Proceedings of the Second International Dharmakirti Conference, Vienna, June 11-16, 1989, 269-80. Wien: Verlag der Österreichischen Akademie der Wissenschaften.

Potter, Karl H. and Sibajiban Bhattacharya. 1977. "Nyāyakusumāñjali." In Karl H. Potter, ed., The Encyclopedia of Indian Philosophies. Volume 2: Indian Metaphysics and Epistemology: The Tradition of Nyāya-Vaiśeșika up to Gañgeśa, 557-88. Delhi: Motilal Banarsidass.

Ruegg, D. Seyfort. 1994. "Pramānabhūta, *Pramāna(bhūta)-puruṣa, Pratyakșadharman and Sākșātkṛtadharman as Epithets of the Rși, Acārya and Tathāgata in Grammatical, Epistemological and Madhyamaka Texts." Bulletin of the School of Oriental and African Studies 57, 2: 303-20.

Varadachari, V. 1977a. "Vyomavatī or Ṭîkā on Praśastapāda's Padārthadharmasaṃraha." In Karl H. Potter, ed., The Encyclopedia of Indian Philosophies. Volume 2: Indian Metaphysics and Epistemology: The Tradition of Nyāya-Vaiśeșika up to Gañgeśa, 425-53. Delhi: Motilal Banarsidass.

Varadachari, V. 1977b. "Ātmatattvaviveka." In Karl H. Potter, ed., The Encyclopedia of Indian Philosophies. Volume 2: Indian Metaphysics and Epistemology: The Tradition of Nyāya-Vaiśeșika up to Gangeśa, 526-57. Delhi: Motilal Banarsidass.

Wezler, Albrecht. 2001. "Some Remarks on Nirukta 1.20 sākșātkṛtadharmāna rșayo, etc." In Axel Michaels, ed., The Pandit: Traditional Scholarship in India, 215-48. Delhi: Manohar Publishers.

\section{Publisher's Note}

Springer Nature remains neutral with regard to jurisdictional claims in published maps and institutional affiliations. 